Transnational Views 



\section{The Changeable Political Map of the Upper Adriatic Region Between Conflict And Coexistence}

\section{Milan BuFon, Koper/Capodistria*}

with 4 tables in the text

\section{Content}

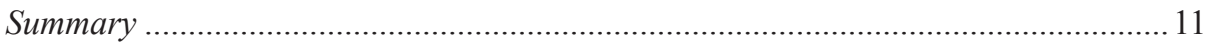

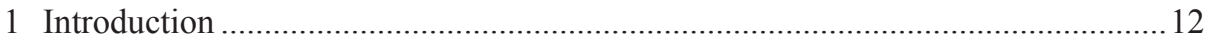

2 The construction of political space in the Upper Adriatic ..................................... 13

3 Changes in ethnic structure within the cultural contact areas of the Upper Adriatic as a consequence of the political partition.................................... 15

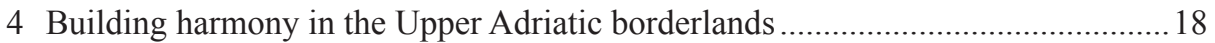

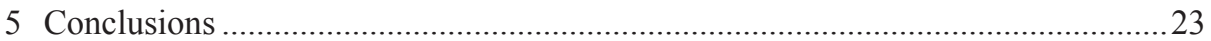

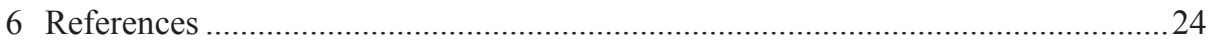

\section{Summary}

The paper presents a geopolitical and political geographical overview of the Upper Adriatic region as an area of contact between different cultural, social, economic and political entities, producing potential of conflicts, particularly in the period of growing nationalism and emerging nation-state formulation in this region. The first part of the $20^{\text {th }}$ century represented a classic example of geopolitical conflict through two world wars and their related peace conferences that produced several versions of political organization of the Upper Adriatic region and a huge number of border proposals. Conflicts arising from the mid-century solution of the so-called Trieste question transformed the Upper Adriatic region into an example in geopolitical handbooks and

* Milan Bufon, Prof. PhD., Institute for Geographical Studies, Science and Research Centre (ZRS), University of Primorska, Titov trg 4, SI-6000 Koper/Capodistria, Slovenia; e-mail: milan. bufon@upr.si 
a real laboratory of contemporary political geographic transformations. Changing geopolitical patterns have also produced considerable modifications in the political, social and ethnic construction of the Upper Adriatic region, driving neighbouring national policies to subordinate the ethno-linguistic structure to the existing state situation. The process of creating new international boundaries in the region actually ended in 1991 with the establishment of an independent Slovenia and Croatia.

In this long period of geopolitical transformations in the Upper Adriatic region an evolution of political-geographic attitudes can also be detected. Early on it followed RATZEL'S geopolitical principles, according to which the flexibility of defining borders directly indicated the change in the power ratio between neighbouring countries, but later it has taken into account to a greater extent modern integrative ideas concerning an increasing interest in looking for harmony and the elimination of international conflicts. Greater attention has thus been given to the political geography of «everyday life», inter-ethnic relations and cross-border contacts.

Research in the area has shown that the «new» borderlands of the Upper Adriatic region are more receptive to integration, because they are seeking to overcome conflicts caused by the division of traditionally homogeneous administrative, social, economic and cultural spaces.

The potential advantages deriving from sharing common spaces among different and hitherto rival ethnic groups on a local level are emerging following the decline or even elimination of political and ideological hindrances on the state level. Since the Upper Adriatic region is now divided among three countries - Italy, Slovenia and Croatia - it is becoming a new and special type of European borderland which will surely increasingly become an object of study for many scholars interested in its social and spatial problems. Moreover, it is now in the best interests of these countries that the region should continue to develop as an area of international and inter-ethnic integration and co-operation, providing thus a possible model of coexistence practices for other European contact areas. After all, the history of the Upper Adriatic region proves that it is much more difficult to divide the region than to bond it together.

\section{Introduction}

The paper will present a political-geographical overview of the Upper Adriatic region as an area of contact between different cultural, social, economic and political entities, producing potential of conflicts, particularly in the period of growing nationalism and emerging nation-state formation in this region. The first part of the $20^{\text {th }}$ century represented a classic example of geopolitical conflict through two world wars and their related peace conferences that produced several versions of political organization of the Upper Adriatic region and a huge number of border proposals. Conflicts arising from the mid-century solution of the so-called Trieste question transformed the Upper 
Adriatic region into an example in geopolitical handbooks and a real laboratory of contemporary political geographic transformations. Changing geopolitical patterns have also produced considerable modifications in the political, social and ethnic construction of the Upper Adriatic region, driving neighbouring national policies to subordinate the ethno-linguistic structure to the existing state situation. The process of creating new international boundaries in the region actually ended in 1991 with the establishment of an independent Slovenia and Croatia.

In this long period of geopolitical transformations in the Upper Adriatic region an evolution of the political-geographic attitude can also be detected. Early on it followed RATZEL's geopolitical principles, according to which the flexibility of defining borders directly indicated the change in the power ratio between neighbouring countries, but later it has taken into account to a greater extent modern integrative ideas showing an increasing interest in looking for harmony and the elimination of international conflicts. Greater attention has thus been given to the political geography of 'everyday life', inter-ethnic relations and cross-border contacts. Research in the area has shown that the 'new' borderlands of the Upper Adriatic region are more receptive to integration, because they are seeking to overcome conflicts caused by the division of traditionally homogeneous administrative, social, economic and cultural spaces. The potential advantages deriving from sharing common spaces among different and hitherto rival ethnic groups on a local level are emerging following the decline or even elimination of political and ideological hindrances on the state level. Since the Upper Adriatic region is now divided among three countries - Italy, Slovenia and Croatia - it is becoming a new and special type of European borderland which will surely increasingly be an object of study for many scholars interested in its social and spatial problems. Moreover, it is now in the best interests of these countries that the region should continue to develop as an area of international and inter-ethnic integration and co-operation, providing thus a possible model of coexistence practices for other European contact areas.

\section{The construction of political space in the Upper Adriatic}

The 'modern' borders in this region have their origin in the $16^{\text {th }}$ century due to the Treaty of Worms between the Republic of Venice and the Habsburg Empire. Interestingly enough, this borders had undergone only minor adjustments until the First World War, and actually still represent the basis of the northern part of the current border between Italy and Slovenia. This border section is therefore one of the oldest and most stable boundaries in Europe.

Its southern part, however, is characterised by instability. After the Second World War this new section of the boundary between Italy and Yugoslavia was based on the totally new criterion of functionally adopted 'ethnic balance'. According to this criterion, 
the border was to coincide as much as possible with the ethnic divide between Italian and Slovene speakers, while at the same time having in both countries the same number of minority group members and the necessary conditions for internal communication. Nevertheless, this criterion created several problems in splitting up traditionally rather persistent integrated regions such as the Gorizia and Istria [Istra] historical regions as well as the Trieste functional region (KLEMENČIČ \& BufON 1991).

In the case of Gorizia, the new political boundary coincided with the ethnic border between the Romance (Italian and Friulan) and Slovenian populations, in the sense that the ethnically mixed town of Gorizia and the transport connections the town needed with Trieste and Udine remained in Italy.

In the case of Istria and Trieste, the principle of 'ethnic balance' was used, since in this region there is no clear territorial ethnic border between the Romance and Slavic (Croatian and Slovenian) population (Moodie 1950). The difficulty of drawing up boundaries in this territory is clear if we consider the fact that for the most problematic segment, Trieste, a temporary solution was found by the creation of the so-called Free Territory of Trieste, itself divided into two zones. Zone A, including the city of Trieste, was ruled by the Anglo-American military forces, whereas Zone B, including Istria, came under Yugoslav rule. This situation was finally solved in 1954, when, with a slight modification of the border, the northern part of the Free Territory of Trieste (Zone A) was left to Italy, while the southern part (Zone B) was left to Yugoslavia. The validity of the entire border was than accepted and confirmed by Italy and Yugoslavia by the Treaty of Osimo in 1978, which introduced also small functional territorial modifications and important proposals for cross-border co-operation (KLEMENČIČ \& BUFON 1991).

A new problem arose with the independence of Slovenia and Croatia in 1991, when the republic boundary drawn along the ethnic border between Croatian and Slovenian population became an international border. At this point a more precise and more rational definition of the border on the ground was needed as it was on the sea, namely in the Gulf of Piran/Pirano - a problem not yet fully solved (GoSAR \& KLEMENČIČ 1994, Gosar \& KLEMENČić 2000). It is interesting to note that these problems also emerged because the Slovenian-Croatian administrative border was based on the ethnic border with no functional modifications, as discussed above. Here, except for the ethnic Italian population in Istria, no national minorities are officially present.

Yet, it should be stressed how even the 'modern' political partitions of the Upper Adriatic in the $20^{\text {th }}$ century have not modified the traditional multicultural nature of that region and how historical inter-ethnic and functional cross-border relations have 'survived' the prevailing 'cuius regio eius religio' homogenization policies. 


\section{Changes in ethnic structure within the cultural contact areas of the Upper Adriatic as a consequence of the political partition}

After the First World War, the increasingly Fascist-like Italian policy of assimilation forced the traditionally ethnically mixed coastal towns to follow the new pattern of Italian 'ethnic purity', and hence they became 'città italianissime'. This in particular was the case with Trieste, where the 1910 census found $30 \%$ of the population in the commune to be Slovenian, whereas only ten years later this figure had decreased to only $8 \%$. According to the analysis of ČERMELJ (1965), after the First World War about 100,000 Slovenians left their homes in the ethnically mixed towns of the occupied territories. The political migrants moved mainly to Yugoslavia, whereas the economic ones moved overseas, to both South and North America. The political emigration of Slovenian population from Trieste continued after World War II, especially after the Yugoslav administration departed, whereas the economic emigration increased after the end of the Free Territory of Trieste and the annexation of Trieste to Italy.

The first two decades after the Second World War were very dynamic and important for Trieste. Even though the number of its inhabitants remained virtually stable (about 250,000 inhabitants), the structure of the population changed radically (see Table 1). In this period, about 50,000 to 60,000 people immigrated from the areas that became part of Yugoslavia, whereas on the other hand about 30,000 to 40,000 people, including many Slovenians, emigrated abroad for economic reasons, mainly to Australia. Also among the immigrants the ethnic structure was different: mostly they were Italians from Istria and Rijeka (Fiume), but there were also from the same areas many Croats, and Slovenes from different part of Slovenia, whose ideas were pro-western and who disagreed with the Tito Communist regime.

Table 1: Change in population structure of Trieste according to birthplace, in 1910 and $1991(\%)$

\begin{tabular}{|l|r|r|}
\hline & 1910 & 1991 \\
\hline Trieste & 49 & 62 \\
\hline Istra & 8 & 14 \\
\hline Western Slovenia & 12 & 1 \\
\hline Italy & 11 & 17 \\
\hline Rijeka and Dalmatia & 2 & 2 \\
\hline Former Yugoslavia & 10 & 1 \\
\hline Austria & 5 & 0 \\
\hline Other countries & 3 & 4 \\
\hline
\end{tabular}

Source: Authors' analysis of statistical data 
Generally speaking, the shift in political boundaries and the annexation of the city to Italy influenced also the immigration flow towards Trieste and hence also the territorial origins of its inhabitants. From the comparison of the situation in 1910 and 1991, an increase of people born in the town (from $49 \%$ to $62 \%$ ) can be seen, this means a decline in immigration dynamics, and indirectly also in attractiveness of the town among hinterland inhabitants.

On the other hand, we can see also a different spatial orientation. Thus the percentage of people that immigrated to Trieste from Italy increased remarkably (from $11 \%$ to $17 \%$ ) as did the number of immigrants from Istria (from $8 \%$ to $14 \%$ ). On the contrary, the number of immigrants from western Slovenia decreased (from 12\% to only $1 \%$ ), as did the number of the immigrants from the rest of Yugoslavia (from 10\% to less than 1\%), and also from Austria (from 5\% to $0 \%$ ). The only figure that remained nearly unchanged is that of the immigrants from Rijeka and Dalmatia (2\%) and from other countries ( $3 \%$ to $4 \%)$.

Also the census figures regarding the ethnic structure of Istria show the impact of political transformations on the ethnic and demographic situation of the area. According to the Austrian census of 1910 there were on the whole peninsula, excluding Trieste and Rijeka, about 250,000 inhabitants - 52\% Italians, 39\% Croats and 9\% Slovenes; whereas according to the 1921 Italian census of a total of 265,000 inhabitants $66 \%$ were Italians, $24 \%$ Croats and 9\% Slovenes. Thus it seems that in a mere decade the number of Italians increased by 50,000, whereas the number of Croats decreased by 30,000 (BufON 2000).

It is clear that such a huge modification in ethnic structure cannot be explained solely by emigration of the native population and by immigration of Italian colonists and state employees. According to SCHIFFRER (1946), the figures of the real ethnic structure were rather distorted. His figures for 1939 are the following: about 150,000 Italians, 97,000 Croats, 44,000 Slovenes and at least 28,000 ethnically mixed inhabitants as well as nearly 10,000 inhabitants of other origin (SCHIFFRER 1946).

What is immediately clear from this analysis, besides the perhaps exaggerated number of Slovenes, is the difficulty of ethnic identification among the population. This can be seen by the big number of ethnically 'neutral' inhabitants, like in north-west Istria, speaking a mixed Croatian-Italian-Slovene dialect that cannot be said to be part of any of the involved ethnic 'parties'. Something similar was noticed by RUTAR (1896) at the end of the $19^{\text {th }}$ century.

All these difficulties of ethnic identification can be seen also in the post-war census of 1948 that somehow turned the statistics of 1921 upside down. Even though the emigration of Italians from Istria actually began in this period, this phenomenon was rather limited in the very first post-war years and therefore does not justify the finding that only 80,000 Italians remained in the region. Obviously many of them, who were included among the Italians 20 years before, changed their minds more or less 'voluntarily'. The real 'exodus' of the Italian population began after 1947 and 
lasted for a decade; by 1961 the number of Italians in Istria had decreased to 20,000, thus about 100,000 native Italians or one third of the whole population had joined the emigration flow. This gap has been only partly filled with new immigrants from the rest of Yugoslavia.

On the other side of the border the majority of the migrants from Istria was settled in the area around Trieste, which has been historically densely inhabited by Slovenes. Thus, a trend towards a 'normalisation' on both sides of the border is evident, which means that the political and ethnic border should better coincide: the north-west coast of Trieste mainly inhabited by Slovenes should have become 'Italian', whereas the western coast of Istria inhabited by Italians should have become 'Yugoslav'.

The influence of 'external' factors on ethnic identification and self-identification is also evident in the later movements of the Italian population in Istria. According to statistics their number had by 1981 decreased to only 13,000. On the contrary, in 1991, when there was a big political and economic crisis in Yugoslavia, the number of Italians increased again to 21,000 (JURI 1991, REPOLUSK 1990).

Usually the biggest changes in ethnic structure occurred in the traditionally ethnically mixed urban centres, to which Italians, Slovenes, Croats, and people of other origin had immigrated during the Austrian period. In this area a remarkable decrease of German population and of other more distant populations can be noticed, as can be seen a decrease in native population depending on nationality (see Table 2). Thus in Trieste

Table 2: Changes in ethnic structure of selected towns in the Upper Adriatic between 1910 and 1991 (in \%)

\begin{tabular}{|l|l|r|r|r|r|}
\hline \multirow{2}{*}{ Gorizia } & & Italians & Slovenes & $\begin{array}{c}\text { Croats and other } \\
\text { Yugosl. nations }\end{array}$ & $\begin{array}{c}\text { Germans and other } \\
\text { nations }\end{array}$ \\
\cline { 2 - 7 } & 1910 & 44.8 & 40.0 & 1.2 & 14.0 \\
\hline \multirow{2}{*}{ Trieste } & 1910 & 77.0 & 14.0 & - & 9.0 \\
\cline { 2 - 6 } & $1991^{*}$ & 84.0 & 10.0 & 1.0 & 9.5 \\
\hline \multirow{2}{*}{$\begin{array}{l}\text { Koper/ } \\
\text { Capodistria }\end{array}$} & 1910 & 78.2 & 18.5 & 3.0 & 3.0 \\
\cline { 2 - 6 } Pula/Pola & 1991 & 2.2 & 82.4 & 1.3 & 1.9 \\
\cline { 2 - 6 } & 1910 & 52.0 & 4.9 & 15.4 & 19.9 \\
\hline \multirow{2}{*}{ Rijeka } & 1991 & 8.1 & 1.9 & 23.2 & 2.0 \\
\cline { 2 - 6 } & 1991 & 48.6 & 4.7 & 88.0 & 19.9 \\
\hline
\end{tabular}

* Estimation

Source: Bufon 1992, Perselli 1993 
a decrease in Slovene population can be seen and at the same time Italian population, which has been traditionally the majority, has increased. In Koper/Capodistria, Pula/ Pola and Rijeka the formerly dominant Italians have withdrawn and have been partly substituted by local Slovene or Croatian population as well as by immigrants from the less developed regions and republics of former Yugoslavia (Gosar 1993). For example, more than $30 \%$ of all immigrants that have moved to Koper/Capodistria were from these areas.

While the census figures show clear trends in ethnic identification and the influences of the political situation, they are not very useful in assessing the 'real' dimension of the ethnic structure, given that the ethnic minority groups often behave like 'submerged' linguistic communities and their 'visibility' depends primarily on the degree of social integration or on the protection measures taken. From more accurate surveys it is evident that in Slovenian Istria only $73 \%$ of the Italian speaking population identify themselves as Italians, and in Croatia this figure is even lower (BogLiuN Debeljuh 1989, 1994, Milani Kruljac 1990). This difference between objective and subjective ethnic identification occurs to an even greater extent among Slovenes in Trieste, whose degree of formal protection is rather inferior. Here only $40 \%$ of the people, who can speak Slovenian or can understand it, identify themselves explicitly as Slovenes (BuFON 1992).

\section{Building harmony in the Upper Adriatic borderlands}

The contemporary image of the Upper Adriatic from a political-geographic point of view is thus completely different from the old image. Ethnic-political transformations in this area have erased to a great extent the formerly persistent ethnic borders. But, even though cultural spaces have lost many of their traditional traits, they still influence the shape of the specific territorial identity, which can be seen by the people who have moved into these places from somewhere else. Moreover, the emigration of native people has widened the space of original regional identity and has been influencing the forms of spatial bonds within a wider regional context (KLEMENČIČ 1993).

In this way, especially the bonds between Trieste and Istria have become stronger, since in and around Trieste now lives the majority of the Istrian native Italians, who are still very bonded to their land of origin. Trieste consequently is becoming, in spite of the two borders that separate it from the rest of Istria, the new 'Caput Istriae', and it is likely that this function will become even stronger in the future, since Istria is devoid of a specific regional centre. Considering that contemporary processes of integration 
follow the principle of 'unity in diversity', it is likely that Trieste can assume again its regional function in this area, on the condition that at the same time its multicultural tradition is revived (MINGHI 1994).

It is a common rule for all 'new' borderlands that after the elimination of political and ideological hindrances, they are the most receptive to new forms of integration between neighbouring countries (BUFON 1994a, 2002). This search for a wider cooperation derives from the process of overcoming the conflicts caused by the division of traditionally homogeneous administrative, social, economic and cultural spaces, and it is becoming quite evident also in the case of the 'three-border' area of Trieste and Istria (SANGuin 1996, ZupanČIČ \& Repolusk 1995). 'Old' borders - and the northern part of the current Italian-Slovene border is a good example of this - are based, in fact, on the 'old' concepts of defining borders, that coincide with the so-called natural, usually orographic boundaries, whereas 'new' borders often penetrate into urban and densely populated areas, where communication among inhabitants used to be intense (Bufon 1993, KlemenčIČ \& Bufon 1994).

This is particularly true for the Gorizia region. Here, the area of the Goriška Brda/ Collio was cut in two and thus lively social and economic relations between the Goriška $\mathrm{Brda} / \mathrm{Collio}$ and Friulian centres, representing the main outlet for the Brda agricultural products, were interrupted. Moreover, the new border hampered the access from the major part of the Goriška Brda/Collio to the villages of Solkan and Šempeter, where a new urban centre, an 'alternative' to the town of Gorizia, was developing, making thus the Goriška Brda/Collio a dead enclave within its own state territory. On the other hand, the very birth of the town of Nova Gorica (The New Gorizia) was unusual not because it meant the construction of a 'twin' town along the border, a relatively frequent phenomenon, - but rather because it had to grow virtually overnight for a precise purpose: that of joining the two villages of Solkan and Šempeter into a larger and more attractive urban centre which would have to overshadow the 'old' Gorizia (Bufon 1996).

These examples show that the border, drawn between Italy and Yugoslavia in 1947, opened up two possible, but extremely different perspectives: on the one hand, the strenghtening of the dividing character of the border and the limitation of crossborder relations would provoke a gradual disintegration of the social and economic tissue of the border area, but on the other, the opening of the border and the promotion of traditional local ties would contribute to the integration and the development of the two border areas.

It is not clear to what extent this dilemma influenced the drawing up of that part of the Peace Treaty in which the two parties are required to jointly solve certain 'technical' problems regarding water and power supply. Nevertheless, the important fact is that already in 1949 the Italian and Yugoslavian governments agreed to make the boundary more permeable, initially only with regard to cross-border traffic of those 
farmers whose land remained on the other side of the border. But from 1955 onwards they agreed to include all local cross-border transit within a range of $10 \mathrm{~km}$ on either side of the border. During the same year local trade within the same area was greatly liberalized.

The effects of these agreements were extraordinary and undoubtedly contributed to the amicable settlement of other open questions and to the creation of a more favorable political climate both at a local and national level. Towards the end of the 1960s, after the abolition of entry visas for international traffic and the stabilization of political relations, the Italian-Yugoslavian border became known as one of the 'most open' boundaries between Western and Eastern Europe, which was undoubtedly true considering the substantially less permeable borders between other neighbour states with profoundly different political systems.

But the openess of the current Italian-Slovene border, particularly with regard to local relations, was even greater than that of many other 'stable' Western European cross-border regions (BUfon 1995). Intense local relations may not be so important from a macro-economic point of view, but they certainly contribute to the shaping and development of more integrated cross-border regions.

In this way, not only the 'berlinization' of both major urban centres along the border was avoided, but the adopted policy also deeply influenced cross-border social and economic transactions. Cross-border trade stemmed on the local level from the rather asymmetric political division: in the Gorizia region, Italy obtained only $8 \%$ of the territory of the former Province of Gorizia, but $74 \%$ percent of its population and $52 \%$ of commercial businesses. It was like an apple cut in two parts: one smaller, but containing the core, the other greater, but without the core. The local border agreements permitted this 'apple' to link up again, and therefore it is not surprising that after the liberalization of local cross-border traffic in 1955, the latter increased in only five years by nearly $900 \%$ (BUfON 2003).

The intensity of the local cross-border traffic has undoubtedly influenced the shaping of a particular and complementary type of economic border space around the towns of Gorizia and Trieste, where the Slovenian area still attracts the inhabitants of the Italian side with its cheaper petrol and food-stuff, restaurants and duty-free shops, as well as its casinos, but also with its better preserved environment, while the Italian border area has been traditionally more attractive for the Slovene neighbours because of its job and shopping opportunities.

A particular phenomenon, which by far exceeds the local cross-border relations, was represented by the Trieste and, on a minor scale, Tarvisio daily shopping fair (MingHI 1999). The former has known its 'golden age' in the 1970s and 1980s thanks to the Yugoslavian shoppers, the latter, instead, has always been an Austrian target.

On the other hand, several researchers (Sussi 1973, Delli ZotTi 1982) have revealed the importance of social cross-border transactions. Investigations revealed 
that economic ties could develop only when local personal cross-border contacts had been established, based on cultural homogeneity, kindships and friendships. On the basis of these contacts several social contacts and other events, such as sports and cultural, could first develop. Only then, could political relations develop. Significantly, these were strenghtened and finally 'normalized' in the late 1970s.

It seems that particularly knowledge of both languages and national or ethnic intertwining of the border population provide for more sophisticated and intense forms of social and cultural cooperation and integration. Traditionally as much as two thirds of local cross-border 'official' contacts were maintained by the Slovene ethnic community in Italy, a minority which is present along the entire Italian-Slovene borderland (BuFON 1994b).

This situation has only partially changed after the independence of Slovenia, even though there are now increasing efforts to give a more structured frame to these extraordinarily intense local cross-border contacts and to create a new Euroregion in the Upper Adriatic, which will most probably be generated by different areas of interest such as the northern border sector, the Gorizia sector, and the Trieste sector, which could also act as the leading Euroregion for the Istrian three-border area.

But besides an increasing process of re-integration of the Upper Adriatic within the frame of the European Union and the established Schengen space, there is also a process of social and spatial dis-integration on the Slovenian-Croatian border, showing how influential remain wider political-geographical transformations on this interesting European contact area.

Recent investigations (BUFON 2008) have revealed that expectations for future developments in cross-border cooperation are quite different among Slovene respondents at the border with Italy and Croatia: positive expectations prevail on the former, whilst negative expectations persist on the latter, as shown in Table 3. Nevertheless, both border areas are sharing the same level of potential social cross-border connection, as $81 \%$ to $83 \%$ of respondents at the border with Italy and Croatia indicated that they have friends living on the other side of the border.

Significantly different is, instead, the structure of functional cross-border traffic, both in terms of intensity and motivations (see Table 4). On the Slovenian-Italian border, as much as $19 \%$ of the population is used to cross the border daily or at least weekly, whilst those types of visits involve only $5 \%$ of the population on the SlovenianCroatian border. Moreover, in this border area not less than $18 \%$ of the population never cross the border in comparison with only $7 \%$ at the border with Italy. For what the motivations for cross-border movements are concerned, shopping prevails at the border with Italy (48\%), whilst the same percentage goes on the border with Croatia for recreation. 
Table 3: Recent convergence and divergence processes in the Upper Adriatic different expectations for the development of cross-border cooperation among Slovene respondents at the border with Italy and Croatia (in \% of respondents)

a) How have croos-border relations changed after Slovenia joined the EU?

\begin{tabular}{|l|r|r|}
\hline & SLO/I & SLO/CRO \\
\hline To the better & 36.0 & 6.0 \\
\hline Remained the same & 55.0 & 29.0 \\
\hline To the worse & 6.0 & 62.0 \\
\hline
\end{tabular}

b) How will cross-border relations change after the Slovenian entrance into the Schengen space?

\begin{tabular}{|l|r|r|}
\hline & SLO/I & SLO/CRO \\
\hline To the better & 49.0 & 14.0 \\
\hline Remain the same & 42.0 & 29.0 \\
\hline To the worse & 4.0 & 52.0 \\
\hline
\end{tabular}

Source: BufON 2008

Table 4: Recent convergence and divergence processes in the Upper Adriatic different structure of cross-border visits among Slovene respondents at the border with Italy and Croatia (in \% of respondents)

a) Intensity of cross-border visits

\begin{tabular}{|l|r|r|}
\hline & SLO/I & SLO/CRO \\
\hline Every day & 7.2 & 1.6 \\
\hline At least once a week & 12.0 & 3.6 \\
\hline At least once a month & 33.5 & 20.2 \\
\hline At least once a year & 40.2 & 56.7 \\
\hline Never & 7.1 & 17.9 \\
\hline
\end{tabular}


b) Motivations for cross-border visits

\begin{tabular}{|l|r|r|}
\hline & SLO/I & SLO/CRO \\
\hline Work & 5.6 & 3.6 \\
\hline Supply & 48.2 & 8.7 \\
\hline Visits to relatives/friends & 17.5 & 15.5 \\
\hline Visits of cultural events & 4.0 & 2.4 \\
\hline Recreation/Excursion & 14.3 & 48.4 \\
\hline
\end{tabular}

Source: BuFON 2008

\section{Conclusions}

The Upper Adriatic is a region of intense cross-border intertwining on a cultural, social, economic and political level. The diffused practice of bilingualism has been in recent times reinforced by developments in local cross-border relations and crossborder information exchange produced by the neighbouring mass media, in which border minorities have taken an important role in creating contact opportunities.

This area provides an interesting illustration of an apparently paradoxical process within borderlands: the greater the conflicts in political partitioning of a previous homogeneous administrative, cultural and economic region, the greater have been opportunities for such a divided area to develop into an integrated cross-border region, once the appropriate conditions are given.

Reflecting on the border landscape concept on the basis of this case study, it becomes clear that the political or economic 'macro' approach in studying cross-border regions is not sufficient. The real qualities of these regions, however, may be found when local cultural and social elements of cross-border relations are taken into account. This great variety of micro-transactions, supported by the border population, is the result of its spatial mobility in satisfying daily needs regarding basic social functions such as shopping, work, leisure time, housing or even education. But they are also the result of the activity of the border population in maintaining traditional cultural links within historical regions.

Hence, the study of border regions undoubtedly brings additional aspects to bear on the standard theory of centre-periphery relations, while opening up a range of new problems and possibilities. Many of these are becoming increasingly more topical in today's world, as we try to enhance our mutual understanding in the culturally rich and diverse European space. The geography of border landscapes in its social and cultural 
dimension is thus definitely assuming an important role in the process of 'humanisation' of the traditional geographical approach to borders and border conflict resolution (RuMLey \& Minghi 1991).

The Upper Adriatic remains therefore a very interesting area subject to continuous geopolitical transformations. Since this area is now divided into three states it is fastly becoming a new and special kind of European borderland or 'Euro-region' where both convergence and divergence processes could be studied, providing thus continuous stimula for boundary researchers. Moreover, the states involved in this region should see that their vested interests are best served by allowing it to remain an area of international and both functional and multicultural integration and co-operation into the future. The history of the Upper Adriatic region proves, after all, that it is much more difficult to divide than to bond it together.

\section{References}

Bogliun Debeljuh L. (1989), Analisi dell'autoidentificazione etnica tra i figli dei matrimoni nazionalmente misti. In: Atti del Convegno Lingue e culture in contatto, pp. 138-149. Fiume, Università degli Studi.

Bogliun Debeljuh L. (1994), L'identità etnica - gli Italiani dell'area istro-quarnerina. Rovigno, Centro di Ricerche Storiche.

Bufon M. (1992), Prostorska opredeljenost in narodna pripadnost: obmejna in etnično mešana območja v evropskih razvojnih silnicah - primer Slovencev v Furlaniji-Julijski krajini. Trst, ZTT.

Bufon M. (1993), Cultural and social dimensions of borderlands: the case of the Italo-Slovene transborder area. In: GeoJournal, 3, pp. 235-240.

Bufon M. (1994a), Local aspects of transborder cooperation: a case study on the Italo-Slovene border landscape. In: Gallusser W. (ed.), Political Boundaries and Coexistence, pp. 1929. Bern, Peter Lang.

Bufon M. (1994b), Nacionalne manjšine in njihova funkcija v mednarodnih integracijskih procesih: iluzija ali realnost? In: ŠTrukelJ I., Sussi E. (eds.), Narodne manjšine danes in jutri, pp. 87-95. Trst, SLORI.

Bufon M. (1995), Prostor, meje, ljudje - razvoj prekomejnih odnosov, struktura obmejnega območja in vrednotenje obmejnosti na Goriškem. Trst, SLORI.

Bufon M. (1996), Social integration in the Italo-Slovene border landscape: the Gorizia transborder region. In: TESG, 3, pp. 247-258.

Bufon M. (2000), Transformations ethniques et geopolitiques en Adriatique septentrionale: entre conflits et perspectives d'integration. In: SANGUIN A.L. (ed.), Mare nostrum: dynamiques et mutations géopolitiques de la Méditerranée, pp. 63-72. Paris, L'Harmattan.

Bufon M. (2002), Confini, identità ed integrazione - nuove prospettive per l'Alto Adriatico. Trieste, SLORI. 
Bufon M. (2003), Cross-border cooperation in the Upper Adriatic. In: Anderson J., O’Dowd L., Wilson T.M. (eds.), New Borders for a New Europe, pp. 177-196. London, Frank Cass.

Bufon M. (2008), Na obrobju ali v osredju? Slovenska obmejna območja pred izzivi evropskega povezovanja. Koper, Annales.

Bufon M., Minghi J. (2000), The Upper Adriatic borderland - from conflict to harmony. In: GeoJournal, 52, pp. 119-127.

ČERmeLu L. (1965), Slovenci in Hrvatje pod Italijo med obema vojnama. Ljubljana, Slovenska Matica.

Delli Zotti G. (1982), Transnational relations in a border region: the case of Friuli-Venetia Julia. In: Strassoldo R., Delli Zotti G. (eds.), Cooperation and Conflicts in Border Areas, pp. 25-60. Milano, Angeli.

Gosar A. (1993), Nationalities of Slovenia - changing ethnic structures in Central Europe. In: GeoJournal, 3, pp. 215-223.

Gosar A., Klemenčič V. (1994), Current problems of border regions along the Slovene-Croatian border. In: Gallusser W.A. (ed.), Political Boundaries and Coexistence, pp. 30-42. Bern, Peter Lang.

Gosar A., KLEmENČić M. (2000), Les problemes de la delimitation de la frontiere Italie-SlovenieCroatie en Adriatique septentrionale. In: SAnguin A.L. (ed.), Mare Nostrum - Dynamiques et mutations geopolitiques de la Mediterranee, pp. 123-134. Paris, L'Harmattan.

JURI F. (1991), Manjšinsko vprašanje v etnično mešanih okoljih: primer Istre. In: Geografija v šoli, 1, pp. 23-25.

KLEMENČIČ V. (1993), National minorities as an element of the demographic and spatial structure of the Alpine-Adriatic-Pannonian region. In: GeoJournal, 3, pp. 207-214.

KLEMENČIČ V., Bufon M. (1991), Geographic problems of frontier regions: the case of the ItaloYugoslav border landscape. In: Rumley D., Minghi J.V. (eds.), The Geography of Border Landscapes, pp. 86-104. London, Routledge.

KLEMENČIČ V., Bufon M. (1994), Cultural elements of integration and transformation of border regions: the case of Slovenia. In: Political Geography, 1, pp. 73-83.

Milani KruljaC N. (1990), La comunità italiana in Istria e a Fiume fra diglossia e bilinguismo (= Etnia, 1). Rovigno, publisher.

Minghi J.V. (1994), The impact of Slovenian independence on the Italo-Slovene borderland: an assessment of the first three years. In: Gallusser W.A. (ed.), Political Boundaries and Coexistence, pp. 88-94. Bern, Peter Lang.

MingHI J.V. (1999), Borderland "day tourists" from the East: Trieste's transitory shopping fair. In: Visions in Leisure and Business, 17, pp. 32-49.

Moodie A.E. (1950), Some new boundary problems in the Julian March. In: Transactions and Papers, Institute of British Geographers, pp. 81-93.

Perselli G. (1993), I censimenti della popolazione dell'Istria, con Fiume e Trieste, e di alcune città della Dalmazia tra il 1850 e il 1936 (= Etnia, IV). Rovigno, Centro di Ricerche Storiche.

Repolusk P. (1990), Spreminjanje narodnostne strukture prebivalstva kot element demogeografskega razvoja v Koprskem primorju. Primorje. In: Zbornik, 15, pp. 107-112.

Rumley D., Minghi J.V. (1991), The Geography of Border Landscapes, pp. 86-104. London, Routledge.

Rutar S. (1896), Trst in mejna grofija Istra. Ljubljana, Matica Slovenska. 
SAnguin A.L. (1996), La 'communaute submergee': les Italiens de l'Istrie croate et slovene. In: Bulletin de l'Association de Geographes Francais, 73, pp. 55-64.

SCHIFFrer C. (1946), La Venezia Giulia: saggio di una carta dei limiti nazionali italo-jugoslavi. Roma.

Sussi E. (1973), L'emergenza della regione transfrontaliera Alpe-Adria: transazioni 'pubbliche' tra Carinzia, Friuli-Venezia Giulia e Slovenia. In: Strassoldo R. (ed.), Confini e regioni, pp. 135-146. Trieste, Lint.

ZupanČič J., Repolusk P. (1995), Regionalism in Istria. In: Koter M. (ed.), Region and Regionalism - Social and Political Aspects, pp. 109-116. Opole - Łódź, University of Lodz, Silesian Institute in Opole. 